This is the author's final, peer-reviewed manuscript as accepted for publication. The publisher-formatted version may be available through the publisher's web site or your institution's library.

\title{
Reducing the energy demand of cellulosic ethanol through salt extractive distillation enabled by electrodialysis
}

Mohammed A.M. Hussain, Peter H. Pfromm

\section{How to cite this manuscript}

If you make reference to this version of the manuscript, use the following information:

Hussain, M. A. M., \& Pfromm, P. H. (2013). Reducing the energy demand of cellulosic ethanol through salt extractive distillation enabled by electrodialysis. Retrieved from http://krex.ksu.edu

\section{Published Version Information}

Citation: Hussain, M. A. M., \& Pfromm, P. H. (2013). Reducing the energy demand of cellulosic ethanol through salt extractive distillation enabled by electrodialysis.

Separation Science and Technology, 48(10), 1518-1528.

Copyright: (c) Taylor \& Francis Group, LLC

Digital Object Identifier (DOI): doi:10.1080/01496395.2013.766211

Publisher's Link:

http://www.tandfonline.com/doi/full/10.1080/01496395.2013.766211\#.Uh-aZtgpjsQ

This item was retrieved from the K-State Research Exchange (K-REx), the institutional repository of Kansas State University. K-REx is available at http://krex.ksu.edu 


\title{
Reducing the Energy Demand of Cellulosic Ethanol through Salt
}

\section{Extractive Distillation Enabled by Electrodialysis}

\author{
Mohammed A.M. Hussain, Peter H. Pfromm* \\ Department of Chemical Engineering, Kansas State University, 1005 Durland Hall, Manhattan, \\ Kansas 66506, U.S.A.
}

\begin{abstract}
One of the main challenges when a biochemical conversion technique is employed to produce cellulosic ethanol is the low concentration of ethanol in the fermentation broth, which increases the energy demand for recovering and purifying ethanol to fuel grade. In this study, two design cases implementing salt extractive distillation - with salt recovery enabled by a novel scheme of electrodialysis and spray drying - along with heat integrated distillation techniques of doubleeffect distillation and direct vapor recompression are investigated through process simulation with Aspen Plus ${ }^{\circledR} 2006.5$ for reducing the thermal energy demand. Conventional distillation along with molecular sieve based dehydration is considered as the base case. Salt extractive distillation along with direct vapor recompression is found to be the most economical ethanol recovery approach for cellulosic ethanol with a thermal energy demand of 7.1 MJ/L (natural gas energy equivalents, higher heating value), which corresponds to a thermal energy savings of $23 \%$ and cost savings of $12 \%$ relative to the base case separation train thermal energy demand and total annual cost.

*Corresponding author: Tel: +1 785532 4312; Fax: +1 7855327372

E-mail: pfromm@ksu.edu
\end{abstract}


Keywords: ethanol, distillation, salt extractive, cellulosic, electrodialysis

\section{Introduction}

Currently, corn-ethanol is the most widely produced biofuel in the U.S (1). The expanded Renewable Fuel Standard (RFS2), established under the Energy Independence and Security Act (EISA) of 2007, mandates the production of $136.3 \mathrm{GL} /$ year of renewable fuels in 2022: 56.8 GL/year of corn-ethanol, $60.6 \mathrm{GL} /$ year of second generation biofuels such as cellulosic ethanol, and 18.9 GL/year of advanced biofuels such as biomass-based diesel. To meet the specific renewable fuel production volume and green house gas emission reduction requirements of RFS2, transitioning of the feedstock from corn to cellulosic sources for future production of bioethanol is considered essential. Cellulosic ethanol can be produced through biochemical and thermochemical conversion processes (2-21). In a biochemical conversion process, the cellulosic feedstock is chemically and/or enzymatically hydrolyzed to sugars to enable microbial fermentation to ethanol. In a thermochemical process, the cellulosic feedstock is gasified to produce syngas which is converted into ethanol through microbial fermentation and/or catalytic reactions. The principal advantages of the biochemical conversion process include relatively low capital costs, less dependence on economy of scale for profitability, and high selectivity and conversion efficiencies $(15,22-24)$. However, there are several key challenges in various areas of the biochemical conversion process that need to be addressed $(3,8,9,11,25)$. In the product recovery area, the main disadvantage is the dilute nature of the fermentation broth with ethanol concentration varying from about 3 to $6 \mathrm{wt} \%,(2,9,10,14,26-29)$ compared to about 10 to 15 wt\% for corn-ethanol (30-34). Recovering ethanol from fermentation broth and purifying to fuel grade is difficult and energy intensive because of the dilute nature of the fermentation broth and 
the challenging water-ethanol vapor liquid equilibrium (VLE) with an azeotrope at about $96 \mathrm{wt} \%$ ethanol and tangential approach of the water-ethanol equilibrium curve to the $45^{\circ}$ line at high ethanol concentrations in the familiar $y$-x VLE diagram representation. Simple distillation cannot be used to distill ethanol above the azeotropic composition. The state of the art technique used in the corn-ethanol industry to produce fuel ethanol is distillation close to the azeotropic composition followed by dehydration in a molecular sieve based adsorption unit (31, 32, 35, 36). This approach can be used for recovering and purifying ethanol from the fermentation broth obtained from cellulosic feedstock. However, there is a drastic increase in the distillation energy demand as the ethanol concentration in the fermentation broth from cellulosic sources is relatively low (30, 37-39).

Heat integrated distillation operations such as multi-effect distillation and vapor recompression can reduce distillation energy demand. These energy saving techniques have been shown to significantly reduce the distillation energy demand for the water-ethanol system (40-51); for instance, distillation energy demand reduction on the order of $42 \%$ has been reported for doubleeffect distillation with split feed compared to conventional distillation with a single column for distilling $93 \mathrm{wt} \%$ ethanol from a feed containing $7 \mathrm{wt} \%$ ethanol (43). Conversely, the VLE of the water-ethanol system can be improved towards ethanol separation by dissolving a salt in the liquid phase to raise the equilibrium vapor ethanol content (52-55). Since salt remains as a nonvolatile component, the VLE of the water-ethanol-salt system can be studied and depicted as a pseudo binary system considering the equilibrium liquid composition on a salt free basis as is commonly done in literature $(54,56-60)$. In addition to "salting out" ethanol this may also break the azeotrope (52, 54, 57). For example, starting with $70 \mathrm{wt} \%$ ethanol in water, $99.6 \mathrm{wt} \%$ ethanol was distilled using potassium acetate as the salt requiring only a quarter of the energy 
needed to obtain an inferior $93 \mathrm{wt} \%$ ethanol by conventional distillation (61). Efficient recovery and reuse of the salt used as the separating agent is, however, crucial. Potassium acetate $(40,57$, 60-66) and calcium chloride (56, 58, 62, 66, 67) have been reported for water-ethanol separation utilizing the "salting out" effect. The use of the salt separating agent in a process with tightly closed water cycles such as the cellulosic bioethanol plant requires that traces of the salt not impact other processing areas negatively. In this study, calcium chloride was selected for the following reasons: low cost, large "salting out" effect $(62,66)$ and compatibility with fermentation.

In a salt extractive distillation column, the salt is usually dissolved in the reflux stream and introduced at the top of the column. Unlike the liquid extractive agents such as ethylene glycol, salt is non volatile and always remains in the liquid phase; thereby, enabling the production of a high purity distillate free of salt. The salt moves downward in the column and is recovered and purified from the distillation column bottoms for re-use in the top of the column. Hence, there are two distinct steps involved: salt extractive distillation and salt recovery/purification. Corrosion due to aqueous ethanolic salt solutions requires consideration in regards to materials of construction $(56,68)$. Other issues are related to solids handling, feeding and dissolving salt in the reflux stream, potential decrease in plate efficiency, and foaming inside the column (52, 54, 57). In the study presented here, the possible benefit in terms of energy demand is established, demonstrating that the concept may be attractive enough to deal with the possible complications.

There are many experimental and theoretical studies $(40,56-58,60-67)$ on producing fuel ethanol by utilizing the "salting out" effect, but most of them focus only on the salt extractive distillation step. Moreover, the studies (40, 52, 54, 56, 60, 63-65) which include both steps of salt extractive distillation and salt recovery do not generally consider techniques other than 
evaporation and drying for salt recovery. Evaporative salt concentration/crystallization and solids drying techniques are energy intensive. Reducing the energy demand for the salt recovery step becomes essential to reap the benefit of salt-induced VLE improvement. In this study, a combination of electrodialysis and spray drying is investigated. The salt extractive column bottoms stream is pre-concentrated by electrodialysis and assumed to be dried to an anhydrous state by spray drying. In electrodialysis, the dilute salt solution is concentrated by selectively separating the salt ions from the solution $(69,70)$ rather than evaporating water; therefore, requiring less energy than that of an evaporative process. Moreover, electrodialysis is rugged and can be operated at high ionic strengths (71). Final recovery of dry salt is achieved through spray drying, which is a widely used unit operation to convert a liquid feed containing salt into dry solid particles in a single step $(72,73)$.

The main goal of this study is to combine the relative advantages of heat-integrated distillation and salt extractive distillation towards reducing the overall energy demand for recovering and purifying ethanol from the fermentation broth of a cellulosic ethanol facility. Two different design cases implementing the heat integrated distillation techniques of double-effect distillation with split feed and direct vapor recompression for stripping ethanol from the fermentation broth, and salt extractive distillation for rectifying the stripped ethanol vapors to fuel grade are considered. Conventional distillation and molecular sieve based adsorption for recovering and purifying ethanol from fermentation broth is considered as the base case with basis process design parameters taken from the National Renewable Energy Laboratory (NREL) process design for cellulosic ethanol production (2). The design cases are investigated for energy demand reduction and economic viability through process simulation and economic analysis with Aspen Plus ${ }^{\circledR} 2006.5$ and Aspen Icarus Process Evaluator ${ }^{\circledR} 2006.5$ respectively. 


\section{Design Cases}

Base case, conventional distillation with molecular sieve based dehydration: Case I

The target fuel ethanol production rate was set at $270 \mathrm{ML}\left(2.1 * 10^{5}\right.$ tonne) per year with an ethanol concentration of 99.5 wt\%. Recovery of ethanol from the fermentation broth and further purification to fuel grade is achieved by two distillation columns (beer column and rectifier) and final water removal by molecular sieve based adsorption as shown in Figure 1. Fermentation broth from the beer well with an ethanol concentration of about $5.5 \mathrm{wt} \%$ is preheated and fed to the beer column operated as a stripper to remove the dissolved carbon dioxide and to produce a vapor distillate with an ethanol concentration of about $44 \mathrm{wt} \%$ and a bottom aqueous stream (stillage), consisting of water, dissolved matter, unfermented solids, proteins, and trace amounts

of ethanol. The stripped carbon dioxide stream from the beer column is treated along with the fermenter offgas in a scrubber for recovering and recycling the residual ethanol to the beer well. The vapor distillate from the beer column is fed to the rectifier, producing an enriched overhead product of about $92 \mathrm{wt} \%$ ethanol and a bottoms aqueous product with trace amounts of ethanol, which is recycled to the process. In the adsorption cycle of the molecular sieve unit, superheated moist ethanol vapor from the rectifier overhead is dehydrated to fuel grade ethanol by the selective adsorption of water, while in the desorption cycle, the molecular sieve adsorber bed is depressurized and purged with dry product ethanol vapors for regeneration. The regeneration stream from the adsorbers is recycled to the rectifier.

Salt extractive process with double-effect beer columns: Case II

The efficient recovery and re-use of salt in salt extractive distillation is of paramount importance in regard to the energy demand, capital cost, and process requirements. Since 
separation and recovery of salt from the highly complex beer column bottoms stream would be a formidable challenge, no salt should be added to the beer column. The rectifier deals with a relatively clean feed stream (the beer column distillate) without solids which facilitates salt recovery from the rectifier bottoms stream. In addition, the VLE of the ethanol-water system is very favorable at the dilute feed conditions. Due to the above reasons, we opted to first strip the fermentation broth, producing a distillate free of solids for subsequent purification in a salt extractive rectifier to fuel grade ethanol. This eliminates the molecular sieve unit. Double-effect distillation with split feed is used to reduce the significant energy demand for stripping ethanol from the fermentation broth. Salt extractive distillation for final purification to fuel grade ethanol is then considered (Figure 2). After initial preheating, fermentation broth from the beer well is treated in a degasser and condenser arrangement to remove the dissolved carbon dioxide, which is sent to the scrubber to recover and recycle the residual ethanol to the beer well. After carbon dioxide removal, the liquid stream from the degasser is split into two streams and fed to two beer columns (BC1 and BC2) operating in parallel. Overhead vapor distillate from BC1 is condensed to provide the reboiling duty of $\mathrm{BC} 2$. The operating pressures of $\mathrm{BC} 1$ and $\mathrm{BC} 2$, and the feed split ratio between them has to be adjusted, respectively, to provide sufficient temperature driving force (weighted logarithmic mean temperature difference, WLMTD $=10 \mathrm{~K}$ ) in the reboilercondenser and to balance the reboiling duty of BC2 with the condensing duty of BC1. Then, the overhead streams from BC1 and BC2 are purified in the salt extractive rectifier directly to fuel grade ethanol. The salt extractive rectifier bottoms stream is divided into diluate and concentrate for the electrodialysis process. After receiving the salt from the diluate, the salt enriched in the concentrate stream is recovered by evaporating the remaining water with hot natural gas 
combustion gases in a co-current spray dryer before recycling to the salt extractive rectifier reflux.

Salt extractive process with direct vapor recompression for beer column, Case III

In Case III (Figure 3), direct vapor recompression reduces the energy demand for stripping the fermentation broth. After removal of carbon dioxide and preheating to essentially saturated liquid conditions, fermentation broth is fed to the beer column. The overhead vapor distillate from the beer column is compressed and then condensed in the reboiler-condenser at the bottom of the beer column; thereby, providing the reboiling duty. Sufficient temperature driving force $($ WLMTD $=10 \mathrm{~K})$ in the reboiler-condenser is maintained by adjusting the compressor outlet pressure. Afterwards, the beer column distillate is purified to the fuel grade level in the salt extractive rectifier as in Case II.

\section{Summary of energy demand comparison approach}

Comparing energy demands for different processing schemes is complex. Heat integration interconnects unit operations, and different qualities of energy $\left(2^{\text {nd }}\right.$ law of thermodynamics based balance, for example, thermal vs. electrical) besides the simple quantity of energy ( $1^{\text {st }}$ law of thermodynamics based balance) impact both economics and environmental issues such as green house gas emissions.

The input data and specified parameters for Case I (base case, Figure 1), Case II (salt extractive process with double-effect beer columns, Figure 2) and Case III (salt extractive process with direct vapor recompression for beer column, Figure 3) are given, respectively, in Table 1, Table 2, and Table 3. Input in all design cases is an identical stream of 412 tonne/h (fermentation broth). Identical streams of fuel ethanol are produced in all of the design cases. 
The liquid water output streams from the design cases are not identical since some water vapor is lost in the spray dryer with the moist air stream in Cases II and III.

The comparison of the energy demand is based on converting all steam and electrical energy to natural gas energy equivalents (higher heating value, HHV) using $80 \%$ boiler efficiency to raise steam and 33\% efficiency for natural gas to electricity. The thermal energy demand of the spray dryer is directly calculated from the natural gas consumption.

\section{Methods}

Process simulation and economic analysis (see Appendix) for the design cases are carried out, respectively, with Aspen Plus ${ }^{\circledR} 2006.5$ and Aspen Icarus Process Evaluator ${ }^{\circledR}$ 2006.5. The thermodynamic property method used in modeling the VLE included the Non-Random Two Liquid model (NRTL) (74) for the liquid phase without electrolytes, the Electrolyte NonRandom Two Liquid model (ENRTL) (75-77) for the liquid phase with electrolytes, the RedlichKwong (R-K) equation of state for the vapor phase (78), and the Henry's law for the dissolved gases. The default property parameters in Aspen Properties ${ }^{\circledR} 2006.5$ are used for all the thermodynamic models except for the ENRTL model. In case of the ENRTL model, the molecule-electrolyte pair parameters and other property parameters are taken from a previous study by the authors (79). The distillation columns are rigorously simulated with the RadFrac module of Aspen Plus ${ }^{\circledR} 2006.5$ using the Newton algorithm. Optimum feed stages for the distillation columns are determined by sensitivity analyses. For modeling the compressor, the Comp block, assuming a centrifugal compressor with a polytropic efficiency of $72 \%$, is used.

For the salt extractive rectifier in Case II and Case III, the important parameters are the total number of stages and the $\mathrm{CaCl}_{2}$ concentration profile. To optimize these parameters, initially the total number of stages is fixed, and then the calcium chloride concentration is optimized. 
Increasing the $\mathrm{CaCl}_{2}$ concentration in the salt extractive rectifier can decrease the reboiler duty because of the improvement in the VLE, but can lead to an increase in salt recovery energy demand because of the increased $\mathrm{CaCl}_{2}$ mass flow. Hence, the $\mathrm{CaCl}_{2}$ concentration in the salt extractive rectifier has to be optimized to achieve a minimum of the sum of the energy requirements for the system. The mass and energy balance calculations for the electrodialyzer, and the spray dryer are separately performed using Microsoft Excel ${ }^{\circledR} 2003$ and Mathcad ${ }^{\circledR} 13$. The results are later incorporated in the overall simulation using the User Model feature of Aspen Plus ${ }^{\circledR}$ 2006.5. After optimizing the calcium chloride concentration in the salt extractive rectifier for different total number of stages, an economic analysis is carried out to determine the optimal total number of stages.

\section{Results and Discussion}

The distillate and bottoms composition for the salt extractive rectifier (Case II, Table 2) has been fixed. Therefore, the main parameters for the salt extractive rectifier are the total number of stages, the reflux (mass flow) and the concentration of salt in this reflux stream.

Initially, the total number of stages is fixed to optimize the reflux rate and concentration of salt in the reflux. The following discussion is for a total stage number of 35. It is necessary to at least eliminate the azeotrope so that fuel grade ethanol can be produced at all in a single salt extractive rectifier. This already occurs at about $2.9 \mathrm{wt} \%$ of $\mathrm{CaCl}_{2}$ in the reflux. Above this concentration, the thermal energy demand of the salt extractive rectifier steeply declines with increasing $\mathrm{CaCl}_{2}$ concentration in the reflux but this benefit levels out above about $9 \mathrm{wt} \%$ (Figure 4). The reason is that the distillation pinch point, the point of contact between the operating line and the VLE curve in a McCabe-Thiele diagram, shifts from the location at high ethanol content (tangent pinch) to the feed stage (feed pinch) due to improvement in the VLE curve with increasing $\mathrm{CaCl}_{2}$ 
concentration. This shift yields the principal benefit of the salt extractive approach above and beyond eliminating the azeotrope. Further increase in the $\mathrm{CaCl}_{2}$ concentration in the reflux causes an increase in $\mathrm{CaCl}_{2}$ mass flow (Figure 5) along with increasing energy demand for salt recovery (Figure 6) without significant added benefit. The overall combined energy demand, therefore, shows a minimum at about $9.3 \mathrm{wt} \% \mathrm{CaCl}_{2}$ in the reflux due to the competition between energy savings due to facilitated distillation, and energy demand for salt recovery (Figure 7). The above mentioned procedure to optimize the concentration of $\mathrm{CaCl}_{2}$ in the reflux is repeated for different total number of stages. When the total number of stages is increased, initially, there is a significant reduction in the overall combined energy demand due to the reduction in the reflux rate and concentration of $\mathrm{CaCl}_{2}$ in the reflux, but this effect levels out above 50 stages (Figure 8). A preliminary economic analysis indicated only marginal annual cost reduction above 50 stages. Hence, 50 stages are considered as economical, and the corresponding optimal concentration of $\mathrm{CaCl}_{2}$ in the reflux is $8.5 \mathrm{wt} \%$. Similar procedure is repeated for the salt extractive rectifier in Case III to find the optimum concentration of $\mathrm{CaCl}_{2}$ in the reflux (Figures 9-12) and the economical total stage number in the salt extractive rectifier (Figure 13), yielding an economical total stage number of 40 , with an optimal calcium chloride concentration of 9.9 wt $\%$ in the reflux.

The results comparing the overall thermal energy demand and process economics for the design cases are shown in Table 4. Recovering ethanol from the fermentation broth and purifying to fuel grade is only considered here for reducing the energy demand, not the overall biomass-tofuel ethanol process. The energy demand for the part of the process considered here is, however, a very significant portion of the energy demand for the overall biomass-to-fuel ethanol process. Both alternative design cases show a substantial thermal energy demand reduction when 
compared to the base case. Case III - salt extractive process with direct vapor recompression for beer column (Figure 14), provides an overall process thermal energy demand reduction of 23.1\%, while Case II - salt extractive process with double-effect beer columns (Figure 15), provides an overall process thermal energy demand reduction of 12.8\%. Case III shows higher thermal energy demand reduction mainly due to the substantial thermal energy demand reduction for the beer column through heat recovery by vapor recompression. Based on the overall process economics, Case III is the most economical process alternative with a total annual cost reduction on the order of MM\$2.4, when compared to the base case.

\section{Conclusions and Outlook}

In this study, two process designs implementing salt extractive distillation together with heat integrated distillation techniques of double-effect distillation and direct vapor recompression are investigated as possible alternatives to a base case comprising conventional distillation and molecular sieve based adsorption for recovering and purifying ethanol from the fermentation broth of a cellulosic fuel ethanol facility. Further, a systematic process simulation procedure is used to optimize the process conditions for salt extractive distillation, with salt recovery enabled by a novel scheme of electrodialysis and spray drying. While, both the design alternatives, Case II - salt extractive process with double-effect beer columns, and Case III - salt extractive process with direct vapor recompression for beer column, show significant thermal energy demand reduction and total annual cost savings, Case III is found to be the best economical alternative. A thermal energy savings potential of $5.7 * 10^{14} \mathrm{~J}$ (as natural gas HHV) per year with a total annual cost savings potential on the order of MM\$2.4 per year can be estimated for producing $270 \mathrm{ML}$ of fuel ethanol (99. $5 \mathrm{wt} \%)$ per year. An overall maximum energy savings potential of $1.3 * 10^{17} \mathrm{~J}$ or about 0.13 Quad (as natural gas HHV) per year could be realized for the targeted 60.6 GL of 
cellulosic biofuel to be produced in the U.S in 2022, if fermentation based cellulosic ethanol is used to achieve this target and the advanced ethanol separation process considered here is implemented.

\section{Acknowledgements}

Support by the Center for Sustainable Energy at Kansas State University is gratefully acknowledged. 


\section{Literature Cited}

(1) Renewable Fuels Association (RFA), 2011. Production Capacity of U.S. Fuel Ethanol Plants: Operational and Under Construction/Expansion. Available at: http://www.ethanolrfa.org/bio-refinery-locations/. Accessed August 4, 2011.

(2) Aden, A.; Ruth, M.; Ibsen, K.; Jechura, J.; Neeves, K.; Sheehan, J.; Wallace, B.; Montague, L.; Slayton, A.; Lukas, J. Lignocellulosic Biomass to Ethanol Process Design and Economics Utilizing Co-current Dilute Acid Prehydrolysis and Enzymatic Hydrolysis for Corn Stover.NREL/TP-510-32438; NREL: 2002.

(3) Kazi, F.K.; Fortman, J.A.; Anex, R.P.; Hsu, D.D.; Aden, A.; Dutta, A.; Kothandaraman, G., (2010) Techno-economic comparison of process technologies for biochemical ethanol production from corn stover. Fuel, 89, S20-S28.

(4) Balat, M.; Balat, H.; Oz, C., (2008) Progress in bioethanol processing. Prog. Energy Combust. Sci., 34, (5), 551-573.

(5) Piccolo, C.; Bezzo, F., (2009) A techno-economic comparison between two technologies for bioethanol production from lignocellulose. Biomass Bioenergy, 33, (3), 478-491.

(6) Cardona, C.A.; Sanchez, O.J., (2007) Fuel ethanol production: Process design trends and integration opportunities. Bioresour. Technol., 98, (12), 2415-2457.

(7) Dwivedi, P.; Alavalapati, J.R.R.; Lal, P., (2009) Cellulosic ethanol production in the United States: Conversion technologies, current production status, economics, and emerging developments. Energy Sustainable Dev., 13, 174-182.

(8) Foust, T.D.; Aden, A.; Dutta, A.; Phillips, S., (2009) An economic and environmental comparison of a biochemical and a thermochemical lignocellulosic ethanol conversion processes. Cellulose, 16, (4), 547-565.

(9) Hamelinck, C.N.; van Hooijdonk, G.; Faaij, A.P.C., (2005) Ethanol from lignocellulosic biomass: techno-economic performance in short-, middle- and long-term. Biomass Bioenergy, $28,(4), 384-410$.

(10) Lynd, L.R., (1996) Overview and evaluation of fuel ethanol from cellulosic biomass: Technology, economics, the environment, and policy. Annu. Rev. Energy Env., 21, 403-465.

(11) Nigam, P.S.; Singh, A., (2011) Production of liquid biofuels from renewable resources. Prog. Energy Combust. Sci., 37, (1), 52-68.

(12) Phillips, S.; Aden, A.; Jechura, J.; Dayton, D.; Eggeman, T. Thermochemical ethanol via indirect gasification and mixed alcohol synthesis of lignocellulosic biomass, Technical report, NREL/TP-510-41168; NREL: 2007. 
(13) Phillips, S.D., (2007) Technoeconomic analysis of a lignocellulosic biomass indirect gasification process to make ethanol via mixed alcohols synthesis. Ind. Eng. Chem. Res., 46, (26), 8887-8897.

(14) Zacchi, G.; Ohgren, K.; Rudolf, A.; Galbe, M., (2006) Fuel ethanol production from steam-pretreated corn stover using SSF at higher dry matter content. Biomass Bioenergy, 30, (10), 863-869.

(15) Ladisch, M.R.; Mosier, N.S.; Kim, Y.; Ximenes, E.; Hogsett, D., (2010) Converting Cellulose to Biofuels. Chem. Eng. Prog., 106, (3), 56-63.

(16) Martin, M.; Grossmann, I.E., (2012) Energy optimization of bioethanol production via hydrolysis of switchgrass. AlChE J., 58, (5), 1538-1549.

(17) Martin, M.; Grossmann, I.E., (2011) Energy optimization of bioethanol production via gasification of switchgrass. AlChE J., 57, (12), 3408-3428.

(18) He, J.; Zhang, W., (2011) Techno-economic evaluation of thermo-chemical biomass-toethanol. Applied Energy, 88, 1224-1232.

(19) Tao, L.; Aden, A., (2009) The economics of current and future biofuels. In Vitro Cell. Dev. Biol.: Plant, 45, 199-217.

(20) Aden, A.; Foust, T., (2009) Technoeconomic analysis of the dilute sulfuric acid and enzymatic hydrolysis process for the conversion of corn stover to ethanol. Cellulose, 16, 535545.

(21) Dutta, A.; Phillips, S.D. Thermochemical ethanol via direct gasification and mixed alcohol synthesis of lignocellulosic biomass, Technical report, NREL/TP 510-45913; NREL: 2009.

(22) U.S. DOE 2006. Breaking the biological barriers to cellulosic ethanol: A joint research agenda, DOE/SC-0095, U.S. Department of Energy Office of Science and Office of Science and Office of Energy Efficiency and Renewable Energy. Available at: www.doegenomestolife.org/biofuels/. Accessed August 2, 2011.

(23) Regulation of Fuels and Fuel Additives: 2011 Renewable Fuel Standards. EPA-HQOAR-2010-0133; FRL-9234-6; Environmental Protection Agency: 2010.

(24) Himmel, M.E.; Ding, S.Y.; Johnson, D.K.; Adney, W.S.; Nimlos, M.R.; Brady, J.W.; Foust, T.D., (2007) Biomass recalcitrance: Engineering plants and enzymes for biofuels production. Science, 315, (5813), 804-807.

(25) Mussatto, S.I.; Dragone, G.; Guimaraes, P.M.R.; Silva, J.P.A.; Carneiro, L.M.; Roberto, I.C.; Vicente, A.; Domingues, L.; Teixeira, J.A., (2010) Technological trends, global market, and challenges of bio-ethanol production. Biotechnol. Adv., 28, (6), 817-830. 
(26) Alzate, C.A.C.; Toro, O.J.S., (2006) Energy consumption analysis of integrated flowsheets for production of fuel ethanol from lignocellulosic biomass. Energy, 31, (13), 24472459.

(27) McAloon, A.; Taylor, F.; Yee, W.; Ibsen, K.; Wooley, R. Determining the Cost of Producing Ethanol from Corn Starch and Lignocellulosic Feedstocks. NREL/TP-580-28893; NREL: 2000.

(28) Wingren, A.; Galbe, M.; Zacchi, G., (2008) Energy considerations for a SSF-based softwood ethanol plant. Bioresour. Technol., 99, (7), 2121-2131.

(29) Zhang, S.P.; Marechal, F.; Gassner, M.; Perin-Levasseur, Z.; Qi, W.; Ren, Z.W.; Yan, Y.J.; Favrat, D., (2009) Process Modeling and Integration of Fuel Ethanol Production from Lignocellulosic Biomass Based on Double Acid Hydrolysis. Energy Fuels, 23, 1759-1765.

(30) Côté, P.; Noël, G.; Moore, S., (2010) The Chatham demonstration: From design to operation of a $20 \mathrm{~m}^{3} / \mathrm{d}$ membrane-based ethanol dewatering system. Desalination, 250, (3), 1060-1066.

(31) Griend, D.L.V. Ethanol Distillation Process. U.S. Patent 7,297,236 B1, Nov 20, 2007.

(32) Kwiatkowski, J.R.; McAloon, A.J.; Taylor, F.; Johnston, D.B., (2006) Modeling the process and costs of fuel ethanol production by the corn dry-grind process. Ind. Crops Prod., 23, (3), 288-296.

(33) Shapouri, H.; Gallagher, P. USDA's 2002 Ethanol Cost-of-Production Survey. Agricultural Economic Report Number 841; United States Department of Agriculture: Washington DC, July 2005.

(34) Summers, D.R.; Ehmann, D. Enhanced V-Grid Trays Increase Column Performance. Presented at the AIChE Annual Meeting, Indianapolis, IN, November 2002.

(35) Swain, R.L.B., Molecular Sieve Dehydrators: Why They Became the Industry Standard and How They Work. In The Alcohol Textbook; Fifth ed.; Ingeldew, W.M., Kelsall, D.R., Austin, G.D., Kluhspies, C., Eds. Nottingham University Press: Thrumpton, U.K., 2009; pp 379-384.

(36) Vane, L.M., (2008) Separation technologies for the recovery and dehydration of alcohols from fermentation broths. Biofuels, Bioprod. Biorefin., 2, (6), 553-588.

(37) Madson, P.W.; Lococo, D.B., (2000) Recovery of volatile products from dilute highfouling process streams. Appl. Biochem. Biotechnol., 84-6, 1049-1061.

(38) Vane, L.M.; Alvarez, F.R., (2008) Membrane-assisted vapor stripping: energy efficient hybrid distillation-vapor permeation process for alcohol-water separation. J. Chem. Technol. Biotechnol., 83, (9), 1275-1287.

(39) Zacchi, G.; Axelsson, A., (1989) Economic-Evaluation of Preconcentration in Production of Ethanol from Dilute Sugar Solutions. Biotechnol. Bioeng., 34, (2), 223-233. 
(40) Lynd, L.R.; Grethlein, H.E., (1984) IHOSR/Extractive distillation for ethanol separation. Chem. Eng. Prog., 59-62.

(41) Boukouvalas, C.; Markoulaki, E.; Magoulas, K.; Tassios, D., (1995) Recovery of nearAnhydrous Ethanol as Gasoline Additive from Fermentation Products. Sep. Sci. Technol., 30, (11), 2315-2335.

(42) Canales, E.R.; Marquez, F.E., (1992) Operation and Experimental Results on a Vapor Recompression Pilot-Plant Distillation Column. Ind. Eng. Chem. Res., 31, (11), 2547-2555.

(43) Collura, M.A.; Luyben, W.L., (1988) Energy-Saving Distillation Designs in EthanolProduction. Ind. Eng. Chem. Res., 27, (9), 1686-1696.

(44) Eakin, D.E.; Donovan, J.M.; Cysewski, G.R.; Petty, S.E.; Maxham, J.V. Preliminary Evaluation of Alternative Ethanol/Water Separation Processes. PNL-3823; Pacific Northwest Laboratory: 1981.

(45) Enweremadu, C.; Waheed, A.; Ojediran, J., (2009) Parametric study of an ethanol-water distillation column with direct vapour recompression heat pump. Energy Sustainable Dev., 13, 96-105.

(46) Larsson, M.; Zacchi, G., (1996) Production of ethanol from dilute glucose solutions - A technical-economic evaluation of various refining alternatives. Bioprocess. Eng., 15, (3), 125132.

(47) Muhrer, C.A.; Collura, M.A.; Luyben, W.L., (1990) Control of Vapor Recompression Distillation-Columns. Ind. Eng. Chem. Res., 29, (1), 59-71.

(48) Oliveira, S.B.M.; Marques, R.P.; Parise, J.A.R., (2001) Modelling of an ethanol-water distillation column with vapour recompression. Int. J. Energy Res., 25, (10), 845-858.

(49) Thibault, J.; Haelssig, J.B.; Tremblay, A.Y., (2008) Technical and economic considerations for various recovery schemes in ethanol production by fermentation. Ind. Eng. Chem. Res., 47, (16), 6185-6191.

(50) Bell, C.J., (1982) Pressure staged distillation of ethanol/water can reduce energy costs. Altern. Energy Sources, 4, (3), 411-418.

(51) Karuppiah, R.; Peschel, A.; Grossmann, I.E.; Martin, M.; Martinson, W.; Zullo, L., (2008) Energy optimization for the design of corn-based ethanol plants. AIChE J, 54, (6), 14991525.

(52) Furter, W.F., (1968) Salt effect in distillation : A technical review. Chem. Eng. (Rugby, U. K.), 46, (5), CE173-CE177.

(53) Furter, W.F., (1977) Salt effect in distillation : A literature-review II. Can. J. Chem. Eng., 55, (3), 229-239. 
(54) Furter, W.F., (1993) Production of fuel-grade ethanol by extractive distillation employing the salt effect. Sep. Purif. Methods, 22, (1), 1-21.

(55) Furter, W.F.; Cook, R.A., (1967) Salt effect in distillation - a literature review. Int. J. Heat Mass Transfer, 10, (1), 23-36.

(56) Barba, D.; Brandani, V.; Digiacomo, G., (1985) Hyperazeotropic ethanol salted-out by extractive distillation - theoretical evaluation and experimental check. Chem. Eng. Sci., 40, (12), 2287-2292.

(57) Cook, R.A.; Furter, W.F., (1968) Extractive distillation employing a dissolved salt as separating agent. Can. J. Chem. Eng., 46, (2), 119-123.

(58) Llano-Restrepo, M.; Aguilar-Arias, J., (2003) Modeling and simulation of saline extractive distillation columns for the production of absolute ethanol. Comput. Chem. Eng., 27, (4), 527-549.

(59) Ohe, S., Vapor Liquid Equilibrium Data - Salt Effect; Editor Ed.^Eds.;Elsevier: New York, 1991.

(60) Torres, J.L.; Grethlein, H.E.; Lynd, L.R., (1989) Computer simulation of the Dartmouth process for separation of dilute ethanol water mixtures. Appl. Biochem. Biotechnol., 20-1, 621633.

(61) Siklós, J.; Timár, L.; Ország, I.; Ratkovics, F., (1982) A simulation of the distillation of ethanol-water mixtures containing salts. Hung. J. Ind. Chem., 10, 309-316.

(62) Cespedes, A.P.; Ravagnani, S.P., (1995) Modelado y simulación del proceso de destilacion extractiva salina de etanol. Inf. Tecnol., 6, (5), 17-20.

(63) Ligero, E.L.; Ravagnani, T.M.K., (2002) Simulation of salt extractive distillation with spray dryer salt recovery for anhydrous ethanol production. J. Chem. Eng. Jpn., 35, (6), 557-563.

(64) Ligero, E.L.; Ravagnani, T.M.K., (2003) Dehydration of ethanol with salt extractive distillation - A comparative analysis between processes with salt recovery. Chem. Eng. Process., $42,543-552$.

(65) Schmitt, D.; Vogelpohl, A., (1983) Distillation of ethanol - water solutions in the presence of potassium acetate. Sep. Sci. Technol., 18, (6), 547-554.

(66) Ravagnani, S.P.; Reis, P.R., (2000) Modelo de orden reducido aplicado a una columna de destilacion extractiva salina. Inf. Tecnol., 11, (2), 43-50.

(67) Pinto, R.T.P.; Wolf-Maciel, M.R.; Lintomen, L., (2000) Saline extractive distillation process for ethanol purification. Comput. Chem. Eng., 24, (2-7), 1689-1694.

(68) Seader, J.D.; Henley, E.J., Separation Process Principles; Editor Ed.^Eds.; Second ed.; Wiley: New York, 2006. 
(69) Sata, T., Ion Exchange Membranes: Preparation, Characterization, Modification and Application; Editor Ed.^Eds.;Royal Society of Chemistry: Cambridge, U.K., 2004.

(70) Strathmann, H., Ion-Exchange Membrane Separation Processes; Editor Ed.^Eds.; Membrane Science and Technology Series, 9 First ed.; Elsevier: Amsterdam, The Netherlands, 2004.

(71) Pfromm, P.H., (1997) Low effluent processing in the pulp and paper industry: Electrodialysis for continuous selective chloride removal. Sep. Sci. Technol., 32, (18), 29132926.

(72) Masters, K., Spray Drying Handbook; Editor Ed.^Eds.; Fourth ed.; George Godwin: London, 1985.

(73) Oakley, D.E., (2004) Spray dryer modeling in theory and practice. Drying Technol., 22, (6), 1371-1402.

(74) Renon, H.; Prausnitz, J.M., (1968) Local compositions in thermodynamic excess functions for liquid mixtures. AIChE J., 14, (1), 135-144.

(75) Chau-Chyun, C.; Britt, H.I.; Boston, J.F.; Evans, L.B., (1982) Local composition model for excess Gibbs energy of electrolyte systems. Part I: Single solvent, single completely dissociated electrolyte systems. AIChE J., 28, (4), 588-596.

(76) Chen, C.C.; Evans, L.B., (1986) A local composition model for the excess Gibbs energy of aqueous-electrolyte systems. AIChE J., 32, (3), 444-454.

(77) Mock, B.; Evans, L.B.; Chen, C.C., (1986) Thermodynamic representation of phaseequilibria of mixed-solvent electrolyte systems. AIChE J., 32, (10), 1655-1664.

(78) Redlich, O.; Kwong, J.N.S., (1949) On the thermodynamics of solutions. V. An equation of state. Fugacities of gaseous solutions. Chem. Rev. (Washington, DC, U. S.), 44, (1), 233-244.

(79) Hussain, M.A.M.; Anthony, J.L.; Pfromm, P.H., (2011) Reducing the energy demand of corn-based fuel ethanol through salt extractive distillation enabled by electrodialysis. AlChE J., doi:10.1002/aic.12577. 


\section{Appendix}

Aspen Icarus Process Evaluator ${ }^{\circledR} 2006.5$ is used to estimate all process equipment cost except for molecular sieve units and the electrodialyzer. In this study, the costs (US\$ basis) are updated using CEPCI - Chemical Engineering Plant Cost Index, and are reported on 2011 first quarter basis. Molecular sieve equipment cost is estimated using the scaling and installation factors taken from Aden et al. (2) while the electrodialyzer equipment cost is estimated using the following equations:

$$
\begin{aligned}
& C_{E D Z}=C_{P}+C_{S} \\
& C_{P}=1.5 \times C_{S} \\
& C_{S}=1.5 \times\left(2 M_{A}\right) \times C_{M} \\
& M_{A}=\frac{Z F n_{S}}{\eta i_{c d}}
\end{aligned}
$$

where $C_{E D Z}$ is the electrodialyzer installed equipment cost, $C_{P}$ and $C_{S}$ are the peripheral and stack costs, respectively, $M_{A}$ is the overall membrane area required for each ion exchange membrane type $\left(\mathrm{m}^{2}\right), Z$ is the ion valence (equivalent/mol), $F$ is the Faraday constant (96485 A.s/equivalent), $n_{s}$ is the salt removal rate (mol/s), $\eta$ is the electrical current efficiency and $i_{c d}$ is the operating current density $\left(\mathrm{A} / \mathrm{m}^{2}\right)$. The following values are used:

$$
\begin{aligned}
C_{M} & =\$ 100 / \mathrm{m}^{2} \\
\eta & =0.9 \\
i_{c d} & =300 \mathrm{~A} / \mathrm{m}^{2}
\end{aligned}
$$

To calculate the annual operating costs $\left(C_{O}\right)$, a plant operation time of $8400 \mathrm{~h} / \mathrm{year}$, and the following utility costs are used: steam $-\$ 17.08 /$ ton, cooling water $-\$ 0.07 /$ ton, process water $\$ 0.53 /$ ton, electricity $-\$ 0.07 / \mathrm{kW} . \mathrm{h}$, and natural gas $-\$ 5.7 / \mathrm{GJ}$ (\$6/MM Btu).

The total annualized cost $(T A C)$ is calculated using the following equations: 
$T A C=C_{O}+A C C R \times T I C$

$$
A C C R=\frac{i(1+i)^{n}}{(1+i)^{n}-1}
$$

where $A C C R$ is the annual capital charge ratio, $T I C$ is the total installed equipment cost, $i$ is the interest rate, and $n$ is the plant life (years). The following values are used:

$$
\begin{aligned}
& i=0.1 \\
& n=10 \text { years (general plant life) } \\
& n=5 \text { years (for membrane replacement cost) }
\end{aligned}
$$

Finally, the total annual cost savings (TACS) is calculated using the following equation:

$$
T A C S=T A C_{\text {Case-I }}-T A C_{\text {Case-II/III }}
$$


List of Tables

Table 1. Input data and specified parameters for Case I - base case, conventional distillation with molecular sieve based dehydration

Table 2. Input data and specified parameters for Case II - salt extractive process with double-effect beer columns

Table 3. Input data and specified parameters for Case III - salt extractive process with direct vapor recompression for beer column

Table 4. Comparison of thermal energy demand and total annual cost savings for the design cases 


\section{Figure Captions}

Figure 1. Process flow scheme for Case I - base case, conventional distillation with molecular sieve based dehydration.

Figure 2. Process flow scheme for Case II - salt extractive process with double-effect beer columns.

Figure 3. Process flow scheme for Case III - salt extractive process with direct vapor recompression for beer column.

Figure 4. Influence of concentration of $\mathrm{CaCl}_{2}$ in reflux on the thermal energy demand of the salt extractive rectifier in Case II (total number of stages $=35$ ).

Figure 5. Influence of concentration of $\mathrm{CaCl}_{2}$ in reflux on the total $\mathrm{CaCl}_{2}$ mass flow to the salt extractive rectifier in Case II (total number of stages $=35$ ).

Figure 6. Influence of concentration of $\mathrm{CaCl}_{2}$ in reflux on the thermal energy demand of the salt recovery units in Case II (total number of stages in the salt extractive rectifier $=35$ ).

Figure 7. Influence of concentration of $\mathrm{CaCl}_{2}$ in reflux on the total thermal energy demand of the salt extractive rectifier (total number of stages $=35$ ) and salt recovery units in Case II.

Figure 8. Influence of total number of stages in the salt extractive rectifier on the total thermal energy demand of the salt extractive rectifier and salt recovery units in Case II.

Figure 9. Influence of concentration of $\mathrm{CaCl}_{2}$ in reflux on the thermal energy demand of the salt extractive rectifier in Case III (total number of stages $=35$ ). 
Figure 10. Influence of concentration of $\mathrm{CaCl}_{2}$ in reflux on the total $\mathrm{CaCl}_{2}$ mass flow to the salt extractive rectifier in Case III (total number of stages $=35$ ).

Figure 11. Influence of concentration of $\mathrm{CaCl}_{2}$ in reflux on the thermal energy demand of the salt recovery units in Case III (total number of stages in the salt extractive rectifier $=35$ ).

Figure 12. Influence of concentration of $\mathrm{CaCl}_{2}$ in reflux on the total thermal energy demand of the salt extractive rectifier (total number of stages $=35$ ) and salt recovery units in Case III.

Figure 13. Influence of total number of stages in the salt extractive rectifier on the total thermal energy demand of the salt extractive rectifier and salt recovery units in Case III.

Figure 14. Thermal energy demand distribution of individual process units in Case II - salt extractive process with double-effect beer columns (total energy demand: 8.1 MJ/L).

Figure 15. Thermal energy demand distribution of individual process units in Case III - salt extractive process with direct vapor recompression for beer column (total energy demand: 7.1 $\mathrm{MJ} / \mathrm{L})$. 
Table 1. Input data and specified parameters for Case I - base case, conventional distillation with molecular sieve based dehydration

\begin{tabular}{lc}
\hline Input Data and Specified Parameters & Base Case \\
\hline Beer Column & 16 \\
Number of Stages & 193.5 \\
Operating Pressure (kPa) & 0.05 \\
Bottoms Ethanol Concentration (wt\%) & \\
Rectifier & 36 \\
Number of Stages & 172.3 \\
Operating Pressure (kPa) & 92.5 \\
Distillate Ethanol Concentration (wt\%) & 0.05 \\
Bottoms Ethanol Concentration (wt\%) & \\
Molecular Sieve Unit ${ }^{\boldsymbol{N}}$ & 389.15 \\
Operating Temperature (K) & 72.3 \\
Purge Stream Ethanol Concentration (wt\%) & 99.5 \\
Fuel Ethanol Concentration(wt\%) & \\
\hline a Data taken from Aden et al.(2). &
\end{tabular}


Table 2. Input data and specified parameters for Case II - salt extractive process with double-effect beer columns

\begin{tabular}{lc}
\hline Input Data and Specified Parameters & Case II \\
\hline Beer Column 1 (BC1) & 15 \\
Number of Stages & 294.4 \\
Operating Pressure (kPa) & 0.05 \\
Bottoms Ethanol Concentration (wt\%) & 0.63 \\
Feed Split & \\
Beer Column 2 (BC2) & 15 \\
Number of Stages & 121.6 \\
Operating Pressure (kPa) & 0.05 \\
Bottoms Ethanol Concentration (wt\%) & 0.37 \\
Feed Split & \\
Reboiler-Condenser & 10 \\
Weighted LMTD (K) & \\
Salt extractive rectifier & $20-60$ \\
Number of Stages & 101.3 \\
Operating Pressure (kPa) & 99.5 \\
Distillate Ethanol Concentration (wt\%) & 0.05 \\
Bottoms Ethanol Concentration (wt\%) & \\
Electrodialysis & 313.15 \\
Operating Temperature (K) & 40 \\
Concentration of CaCl ${ }_{2}$ in Concentrate (wt\%) & 90 \\
Current Efficiency (\%) & \\
Spray Dryer & 923.15 \\
Hot Gas Temperature (K) & 473.15 \\
Moist Gas Temperature (K) & \\
\hline & \\
\hline
\end{tabular}


Table 3. Input data and specified parameters for Case III - salt extractive process with direct vapor recompression for beer column

\begin{tabular}{lc}
\hline Input Data and Specified Parameters & Case III \\
\hline Beer Column & 15 \\
Number of Stages & 101.3 \\
Operating Pressure (kPa) & 0.05 \\
Bottoms Ethanol Concentration (wt\%) & \\
Compressor & 229.1 \\
Outlet Pressure (kPa) & \\
Reboiler-Condenser & 10 \\
Weighted LMTD (K) & \\
Salt extractive rectifier & $20-50$ \\
Number of Stages & 101.3 \\
Operating Pressure (kPa) & 99.5 \\
Distillate Ethanol Concentration (wt\%) & 0.05 \\
Bottoms Ethanol Concentration (wt\%) & \\
Electrodialysis & 313.15 \\
Operating Temperature (K) & 40 \\
Concentration of CaCl ${ }_{2}$ in Concentrate (wt\%) & 90 \\
Current Efficiency (\%) & \\
Spray Dryer & 923.15 \\
Hot Gas Temperature (K) & 473.15 \\
Moist Gas Temperature (K) & \\
\hline
\end{tabular}


Table 4. Comparison of thermal energy demand and total annual cost savings for the design cases

\begin{tabular}{|c|c|c|c|c|c|}
\hline $\begin{array}{l}\text { Design } \\
\text { Variant }^{a}\end{array}$ & $\begin{array}{l}\text { Thermal } \\
\text { Energy } \\
\text { Demand } \\
(\mathrm{MJ} / \mathrm{L})\end{array}$ & $\begin{array}{l}\text { Total Installed } \\
\text { Equipment } \\
\text { Cost } \\
\text { (MM\$) }\end{array}$ & $\begin{array}{l}\text { Thermal Energy } \\
\text { Demand } \\
\text { Reduction } \\
\text { (\%) }\end{array}$ & $\begin{array}{l}\text { Total } \\
\text { Annual } \\
\text { Cost } \\
\text { Savings } \\
\text { (MM\$/year) }\end{array}$ & $\begin{array}{l}\text { Total Annual } \\
\text { Cost Savings } \\
(\%)\end{array}$ \\
\hline Case I & 9.2 & 9.6 & -- & -- & -- \\
\hline Case II & 8.1 & 11.8 & 12.8 & 1.6 & 8.1 \\
\hline Case III & 7.1 & 17.3 & 23.1 & 2.4 & 12.4 \\
\hline
\end{tabular}

${ }^{a}$ Case I: Base case, conventional distillation with molecular sieve based dehydration; Case II: Salt extractive process with double-effect beer columns; Case III: Salt extractive process with direct vapor recompression for beer column. 


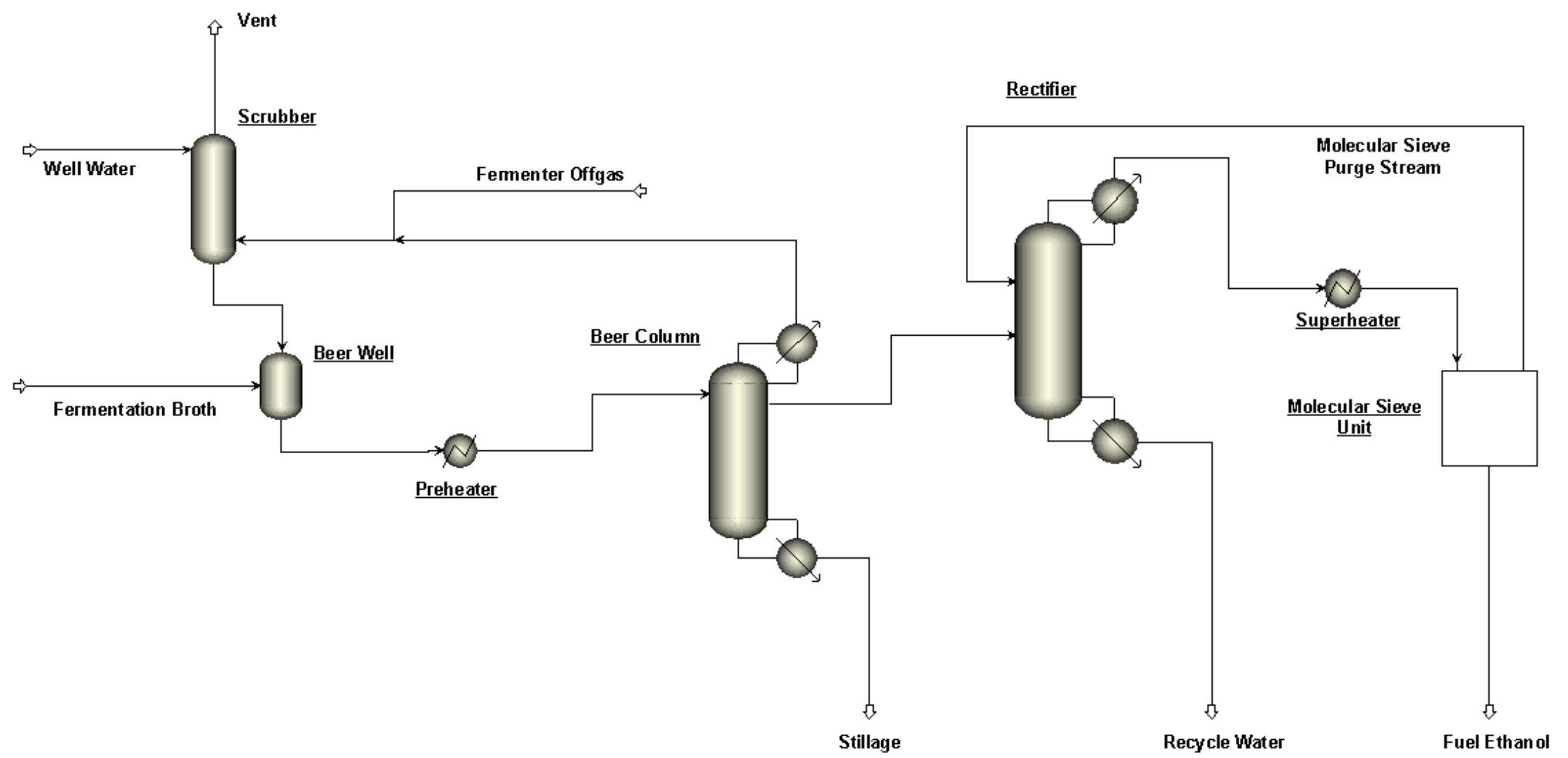

Figure 1 


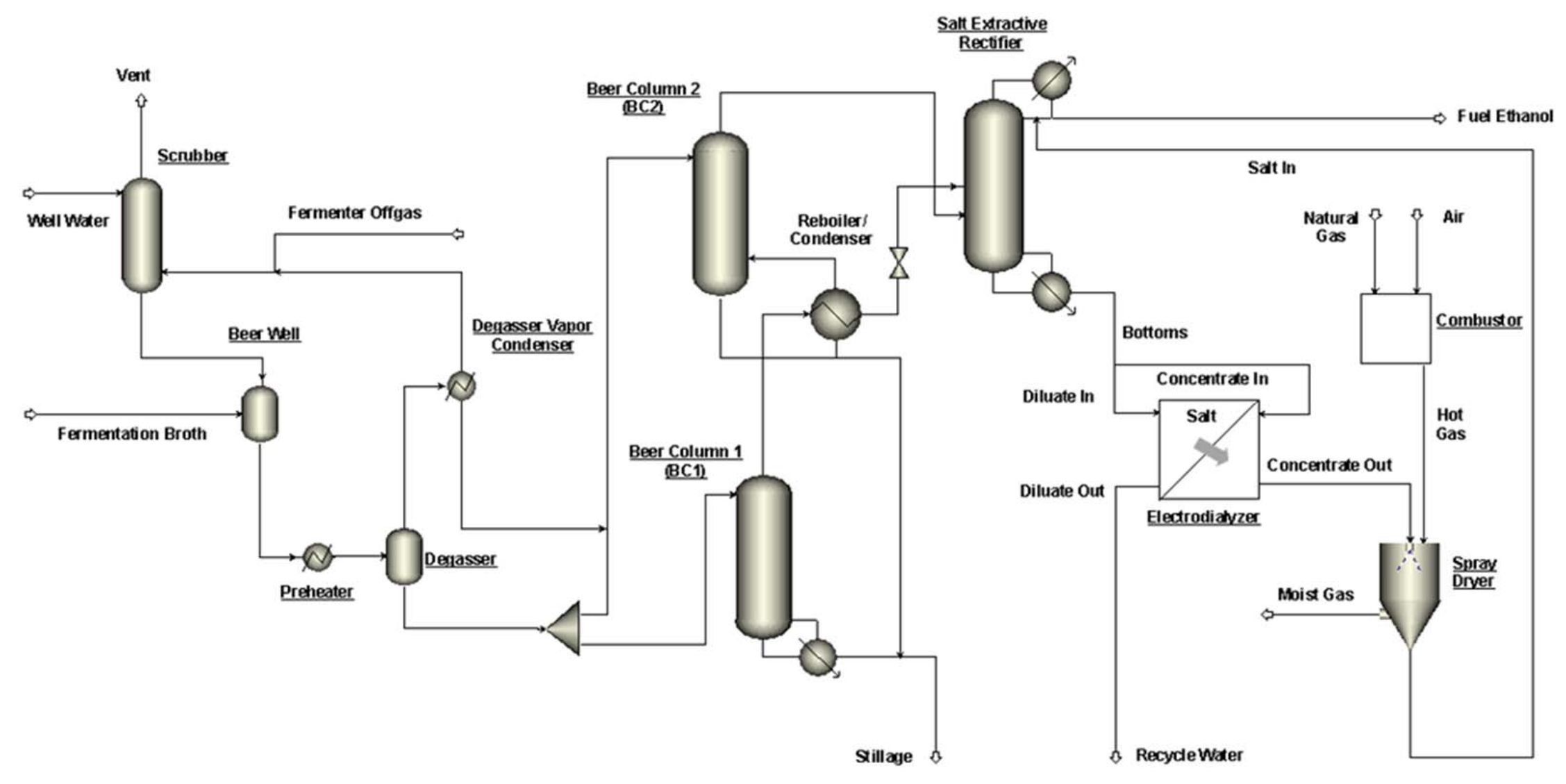

Figure 2 


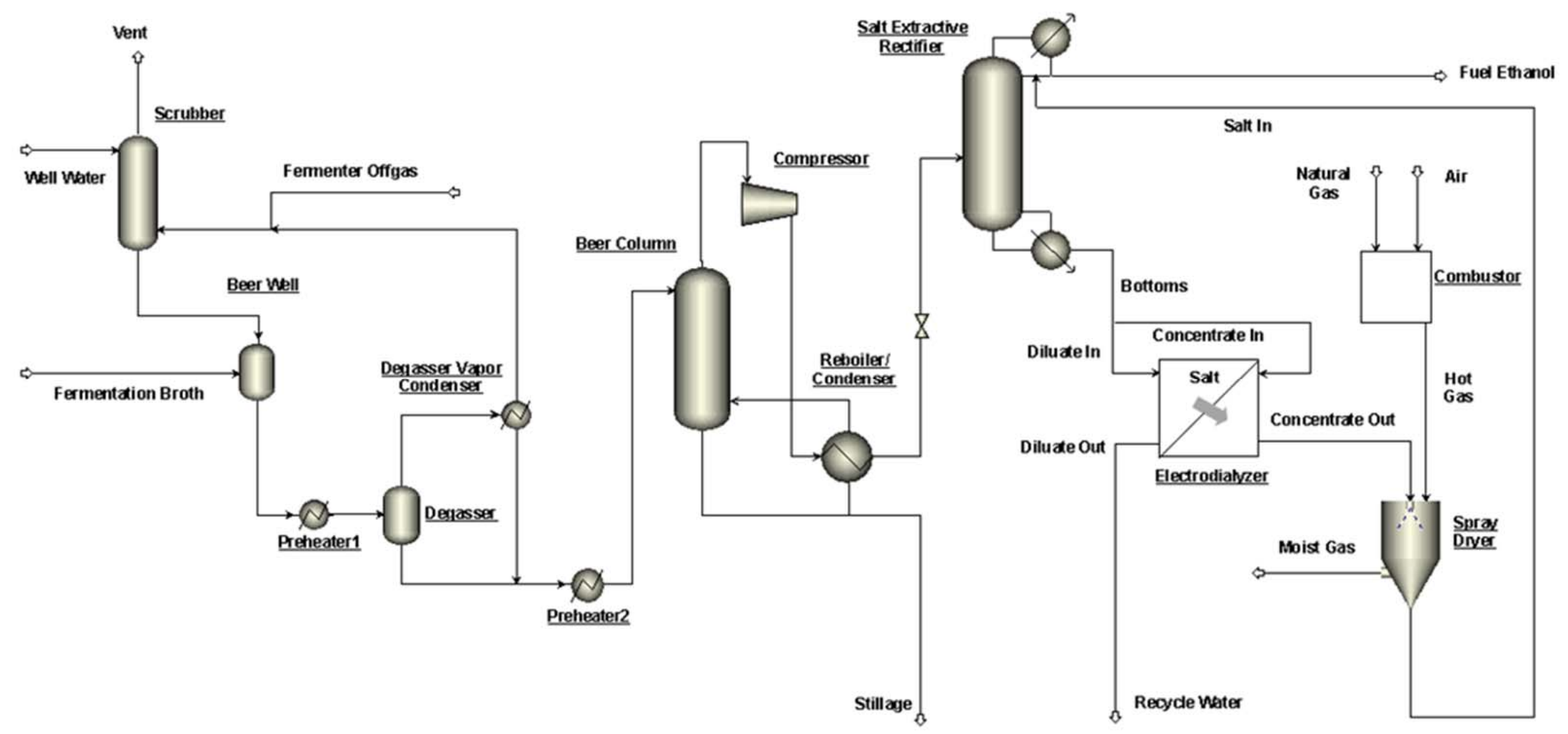

Figure 3 


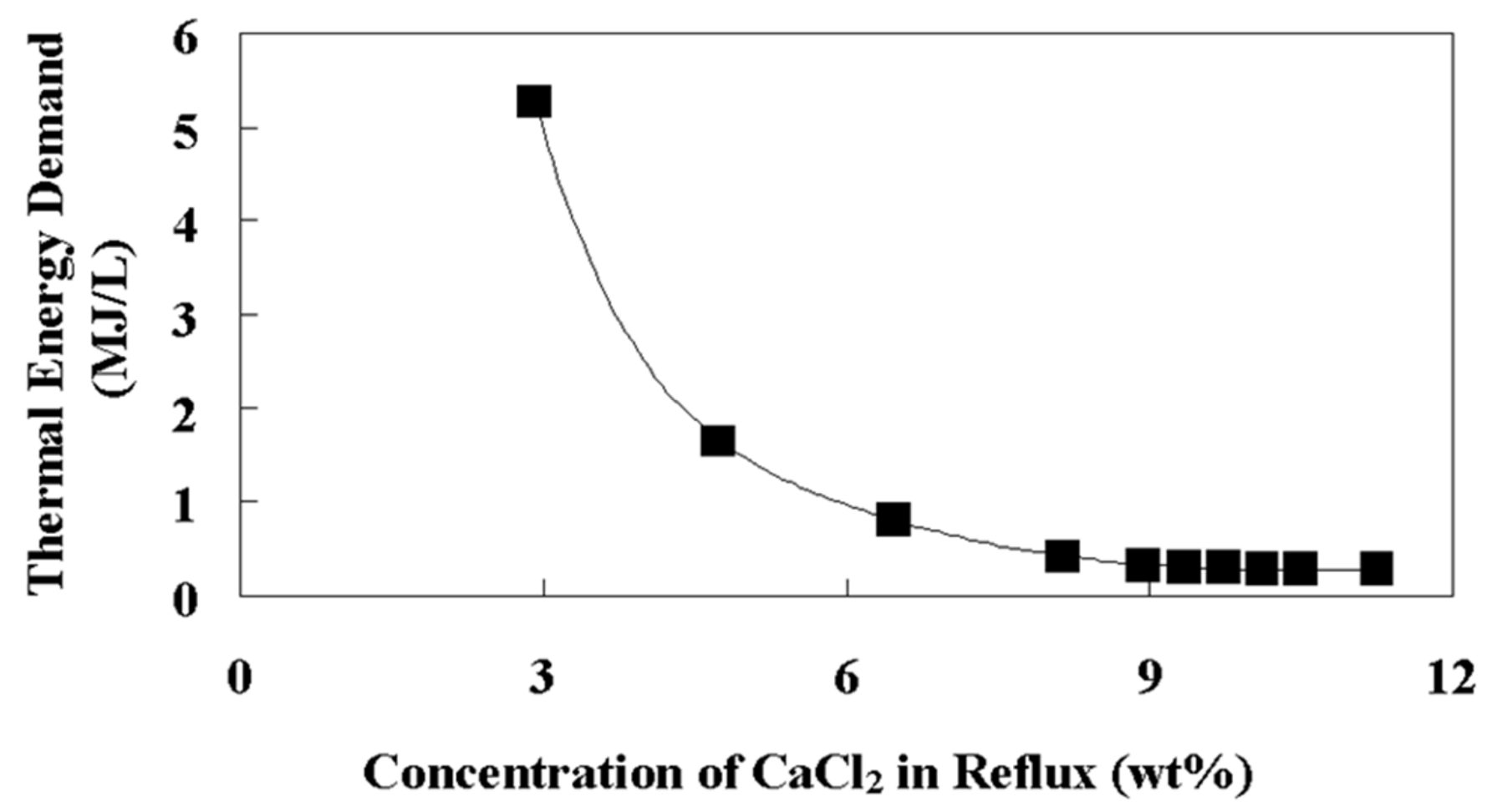

Figure 4 


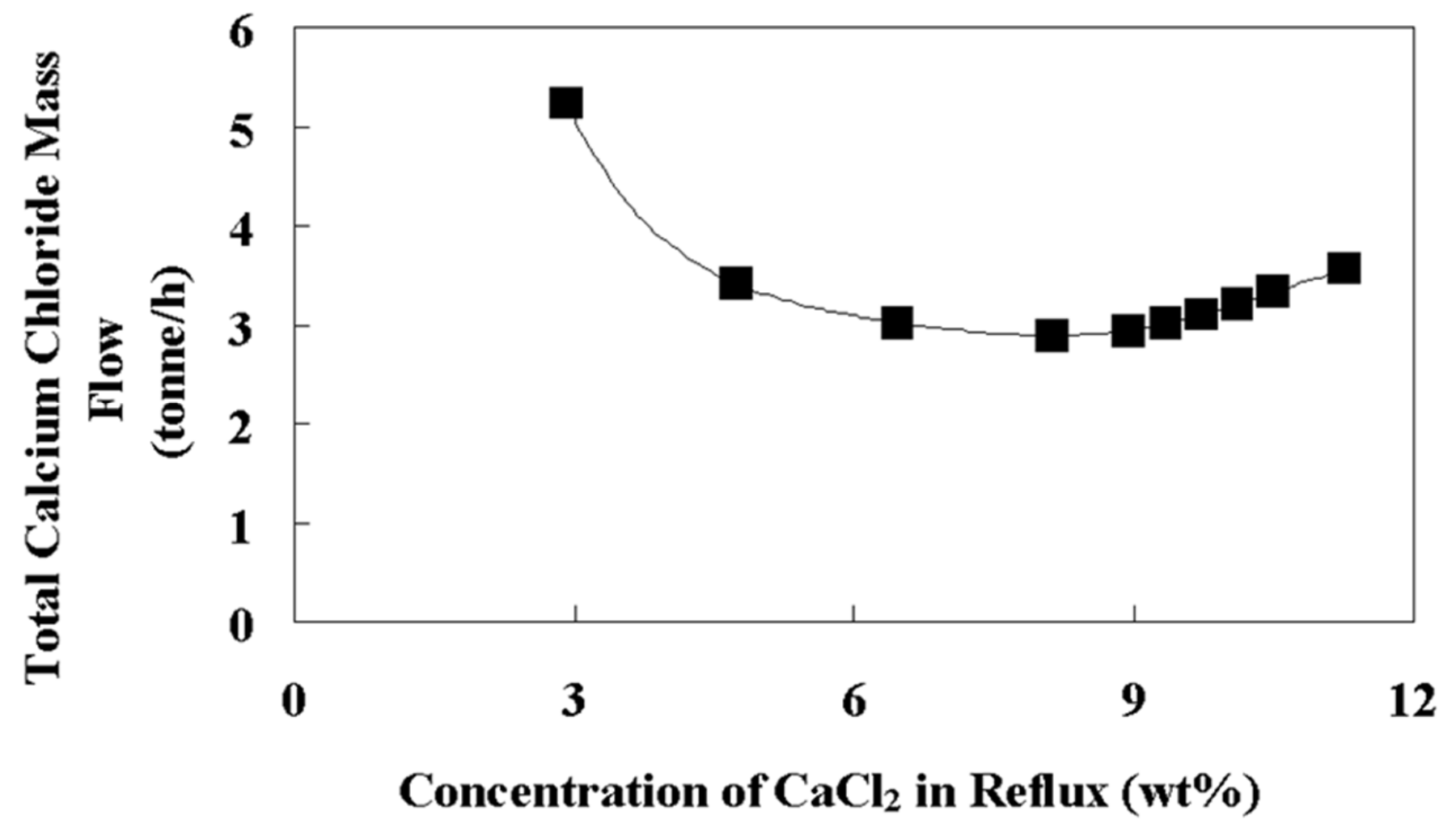

Figure 5 


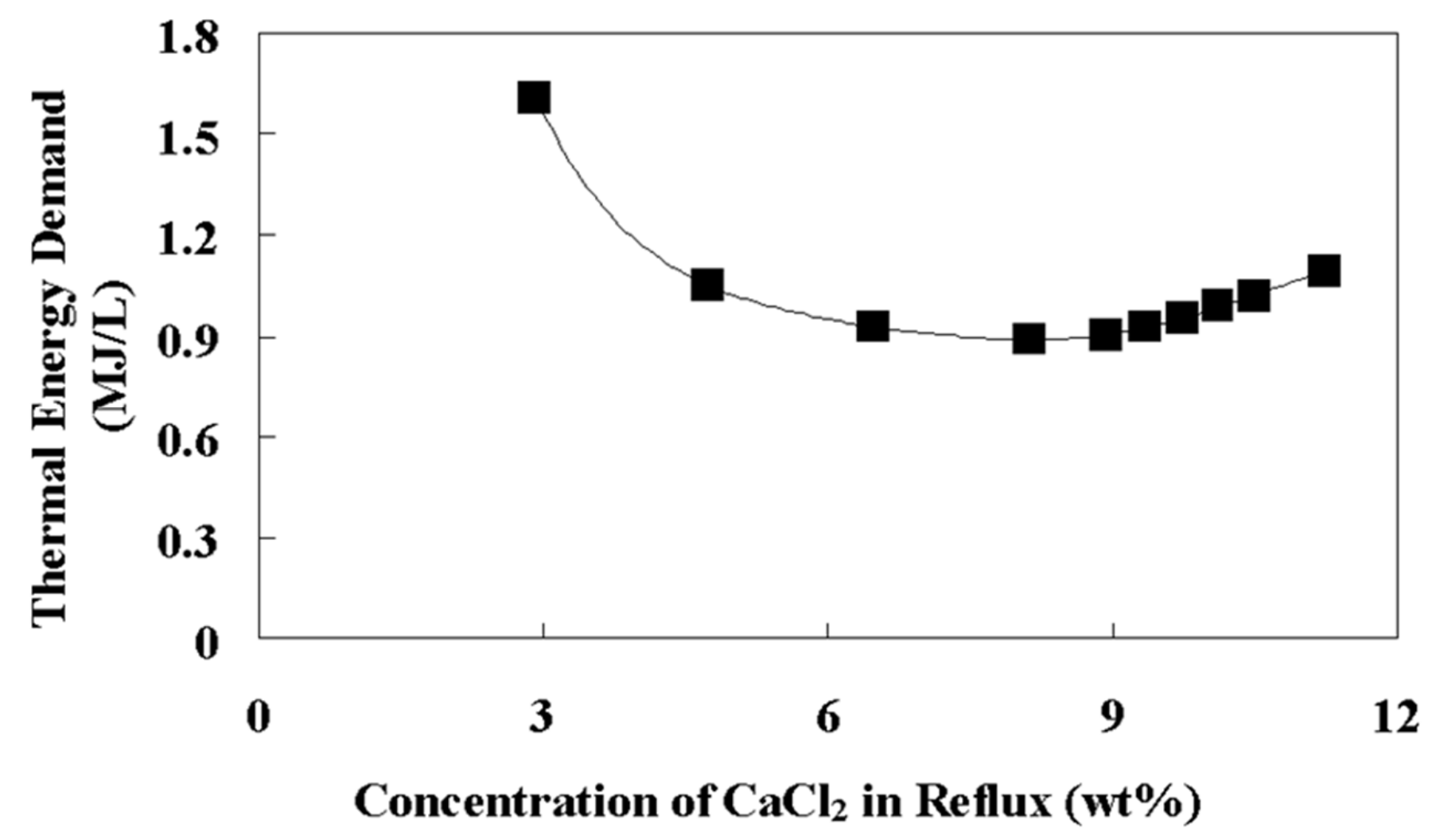

Figure 6 


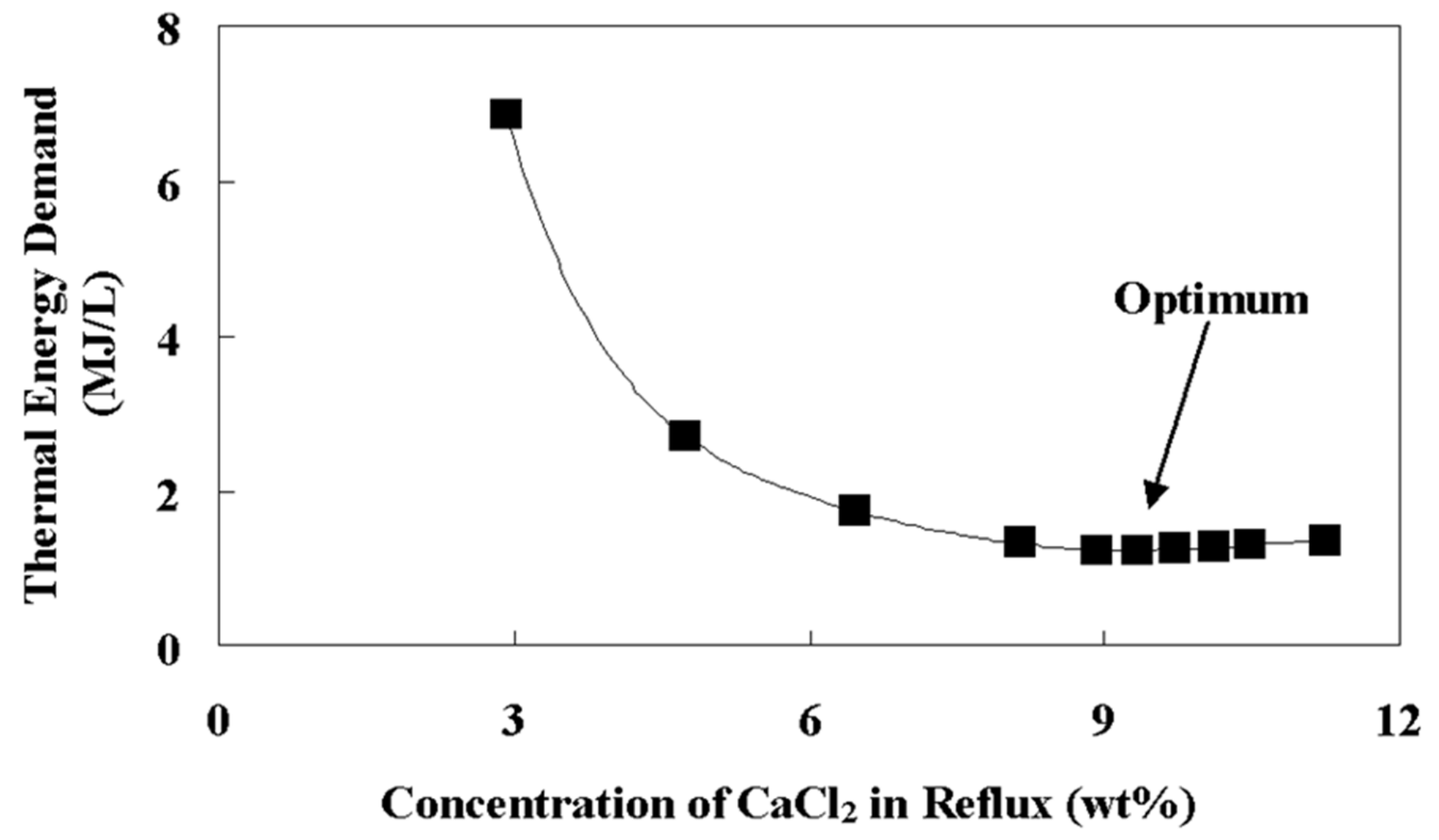

Figure 7 


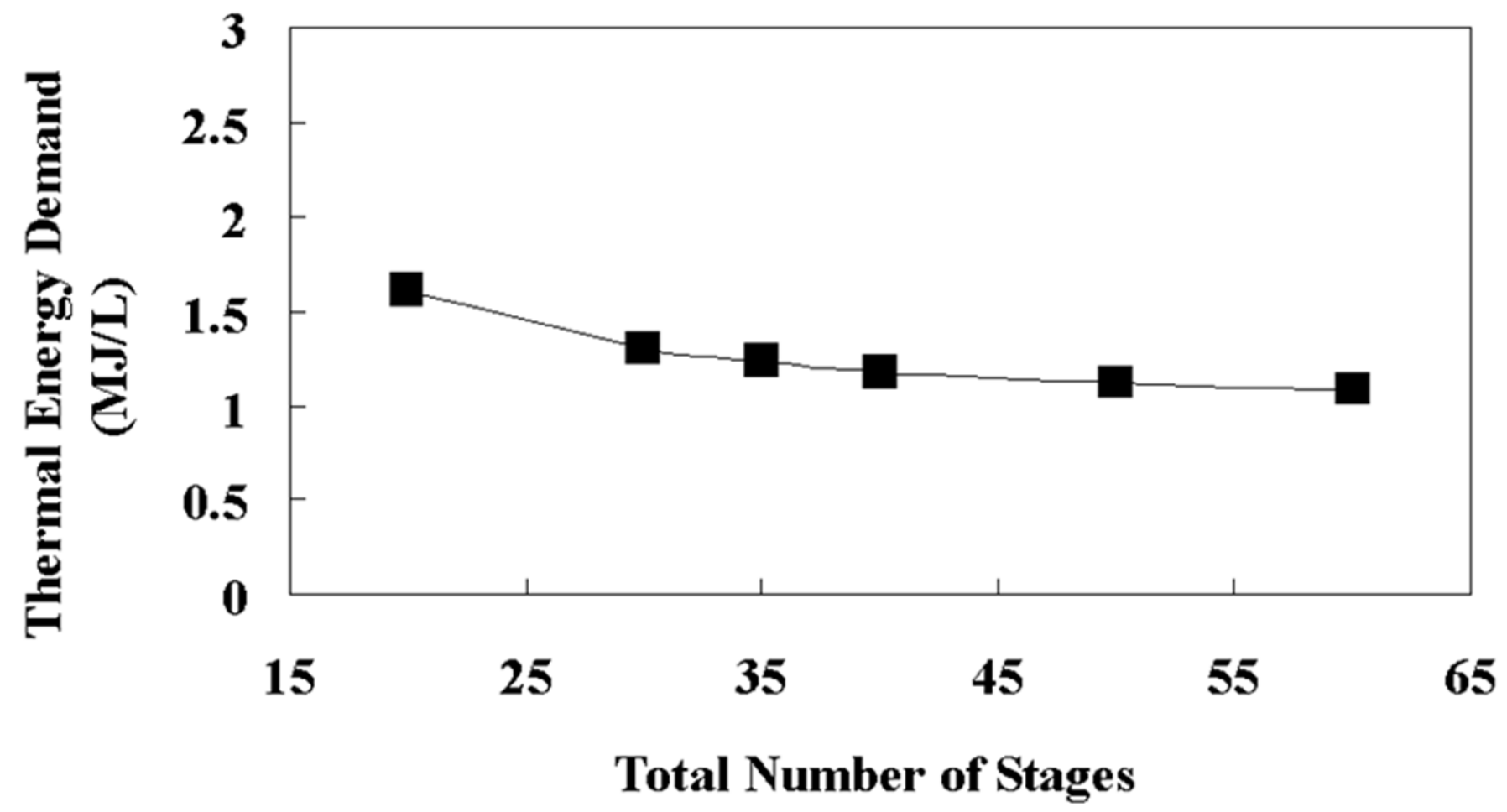

Figure 8 


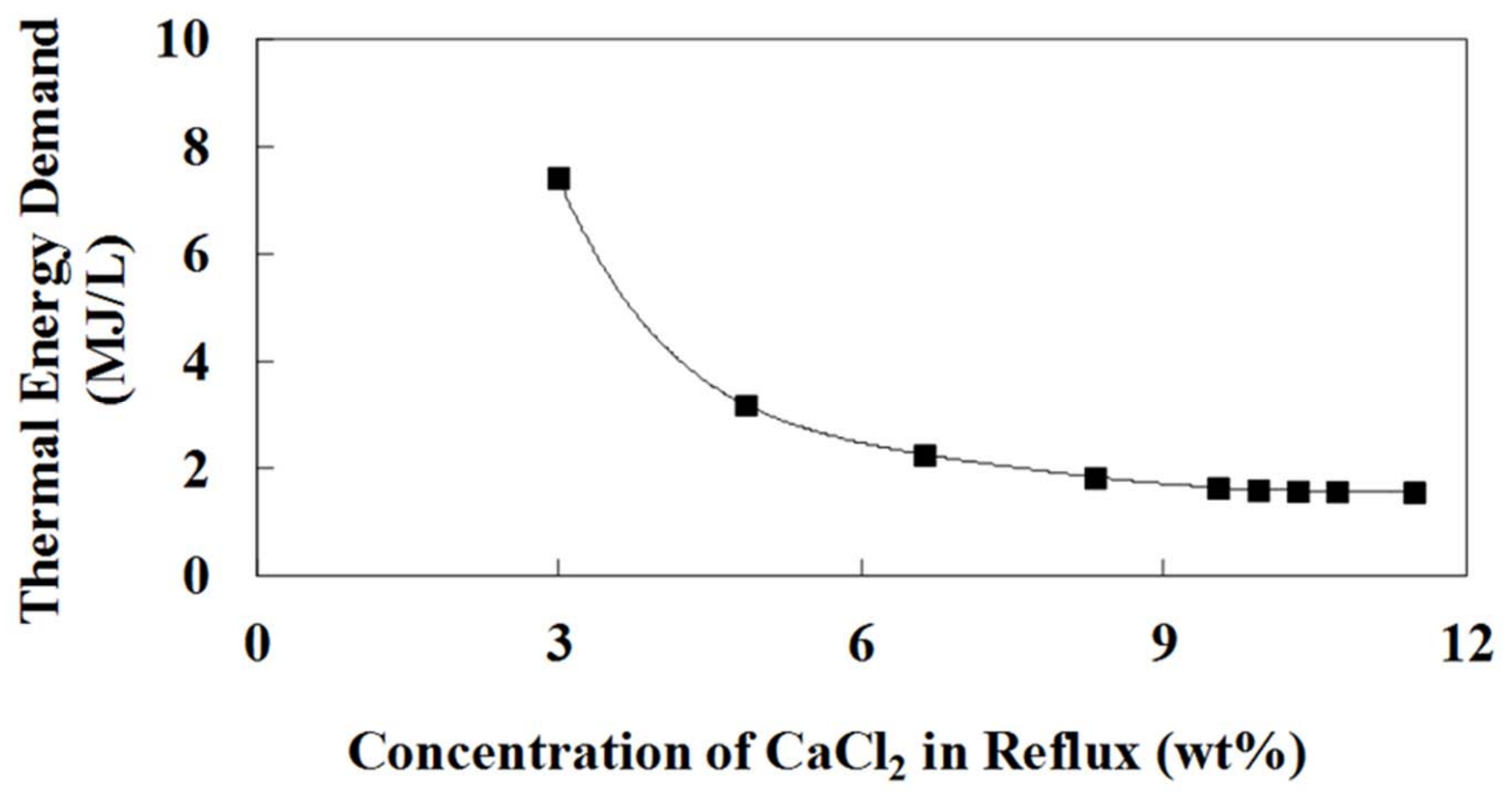

Figure 9 


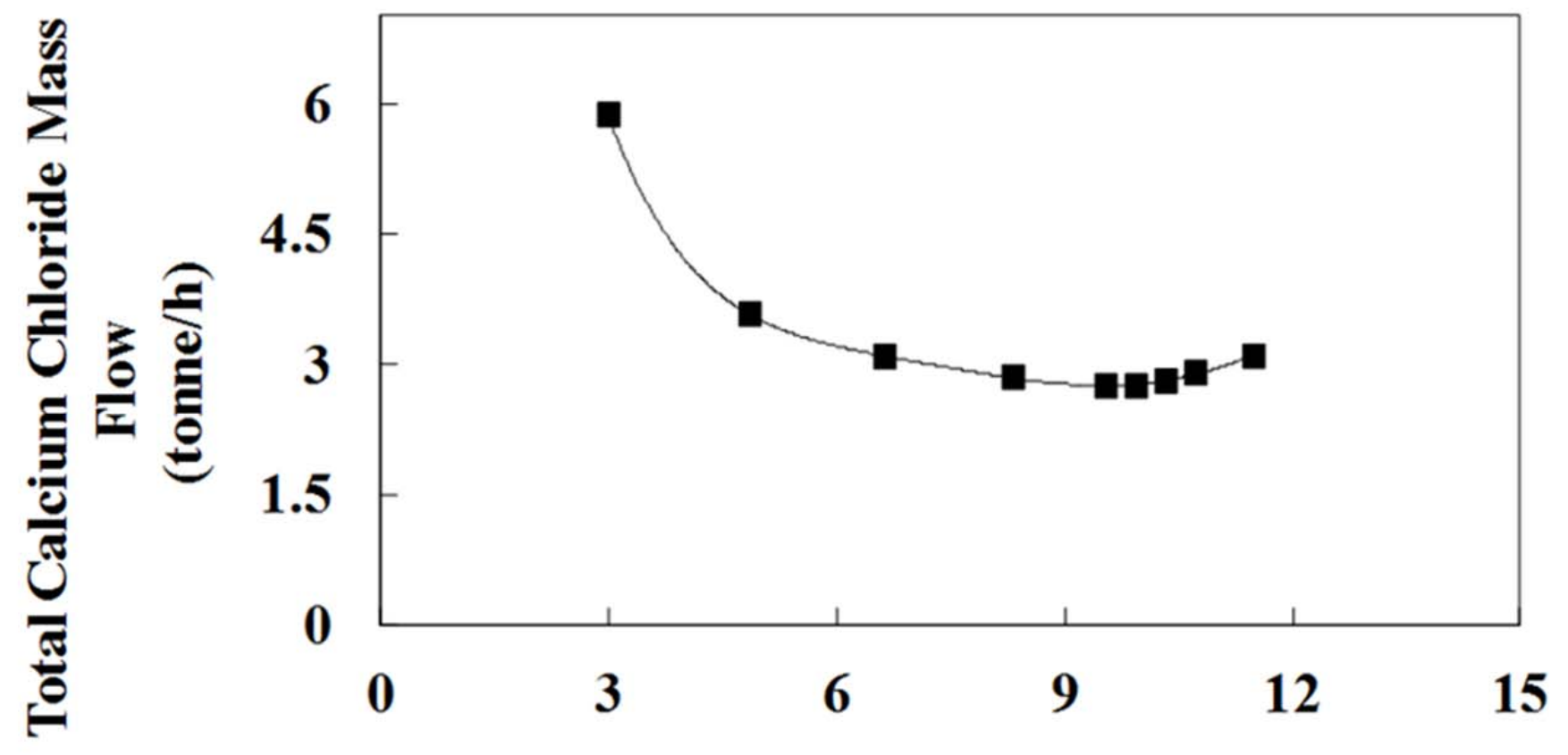

Concentration of $\mathrm{CaCl}_{2}$ in Reflux (wt\%)

Figure 10 


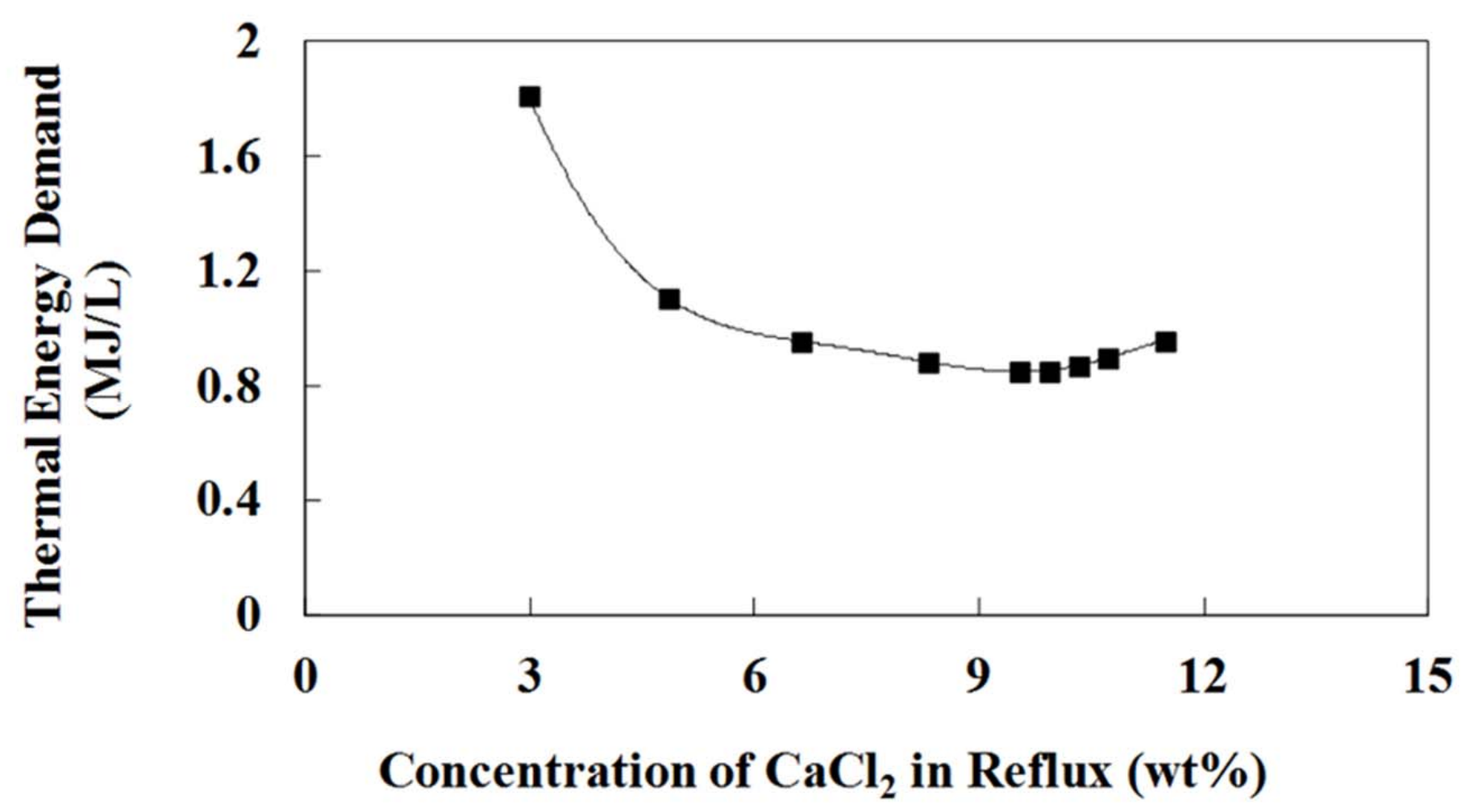

Figure 11 


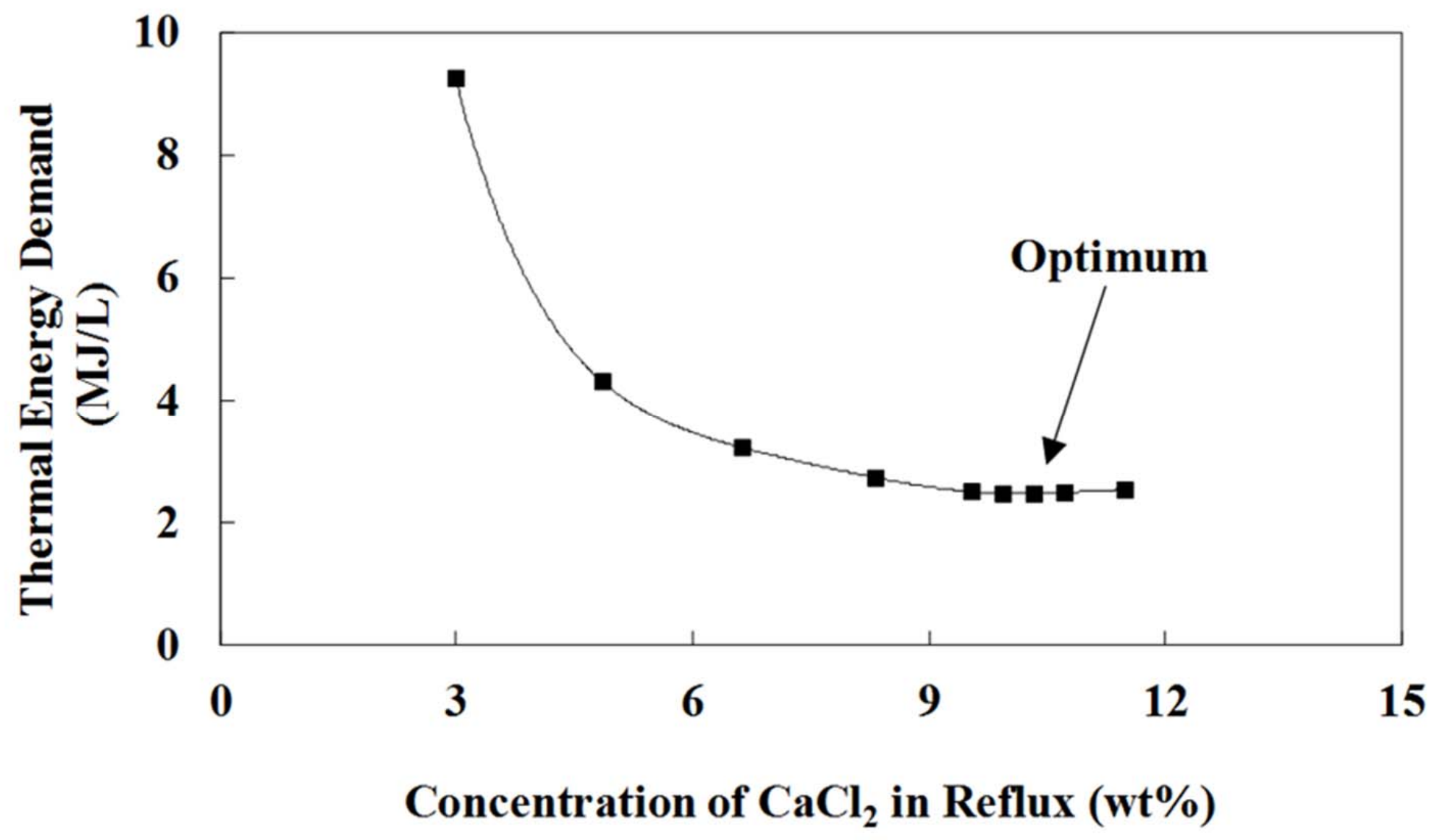

Figure 12 


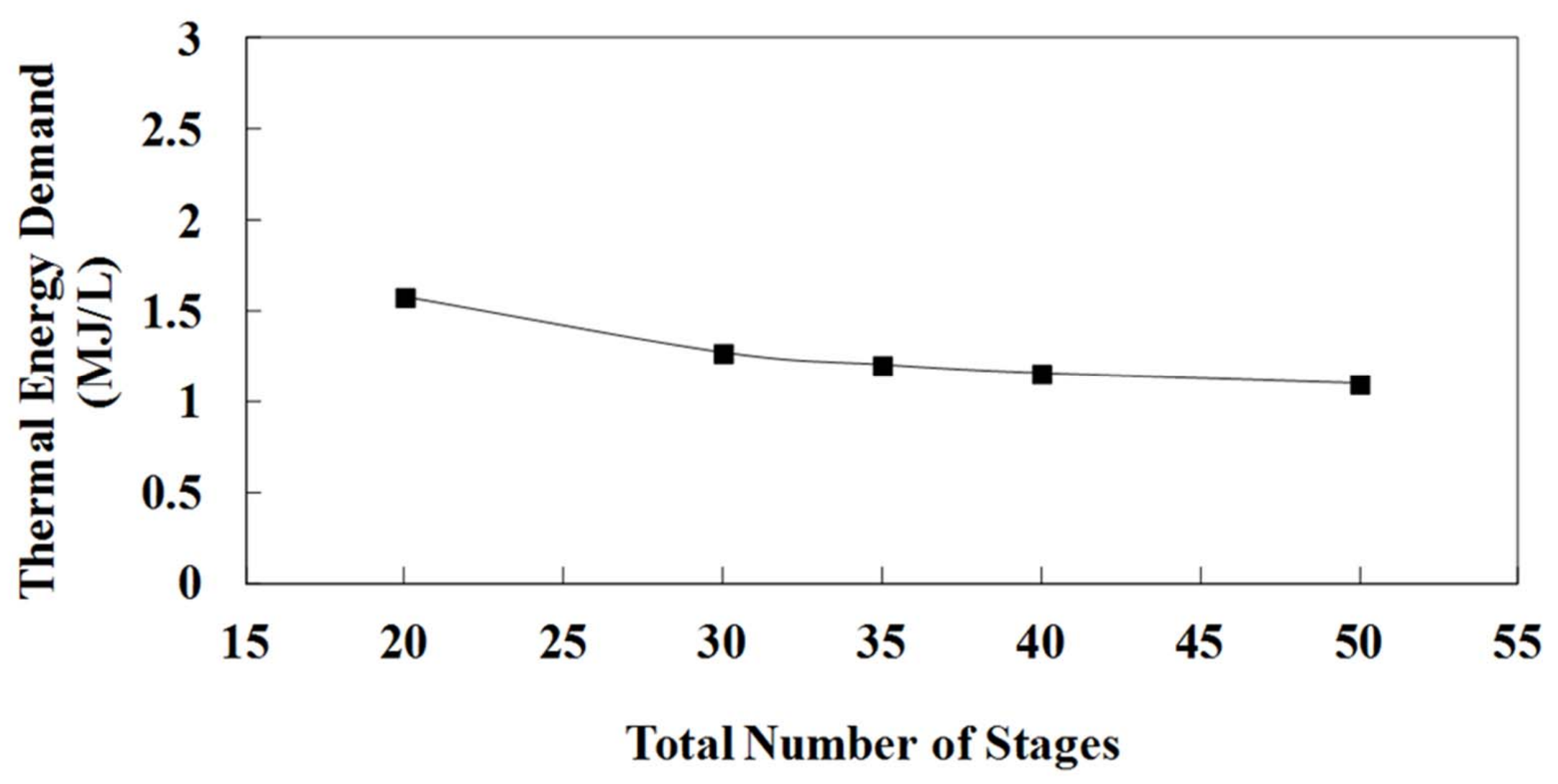

Figure 13 


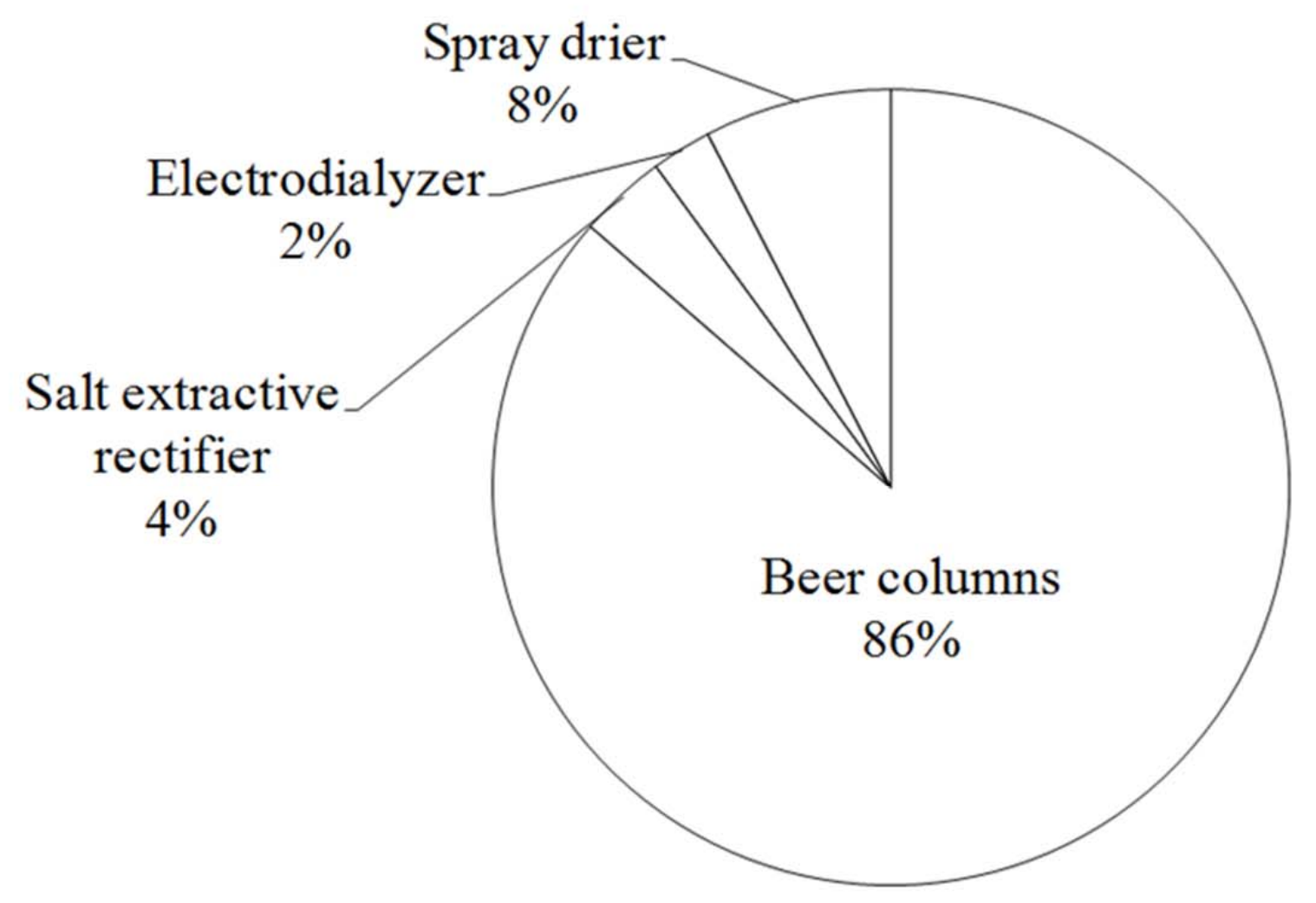

Figure 14 


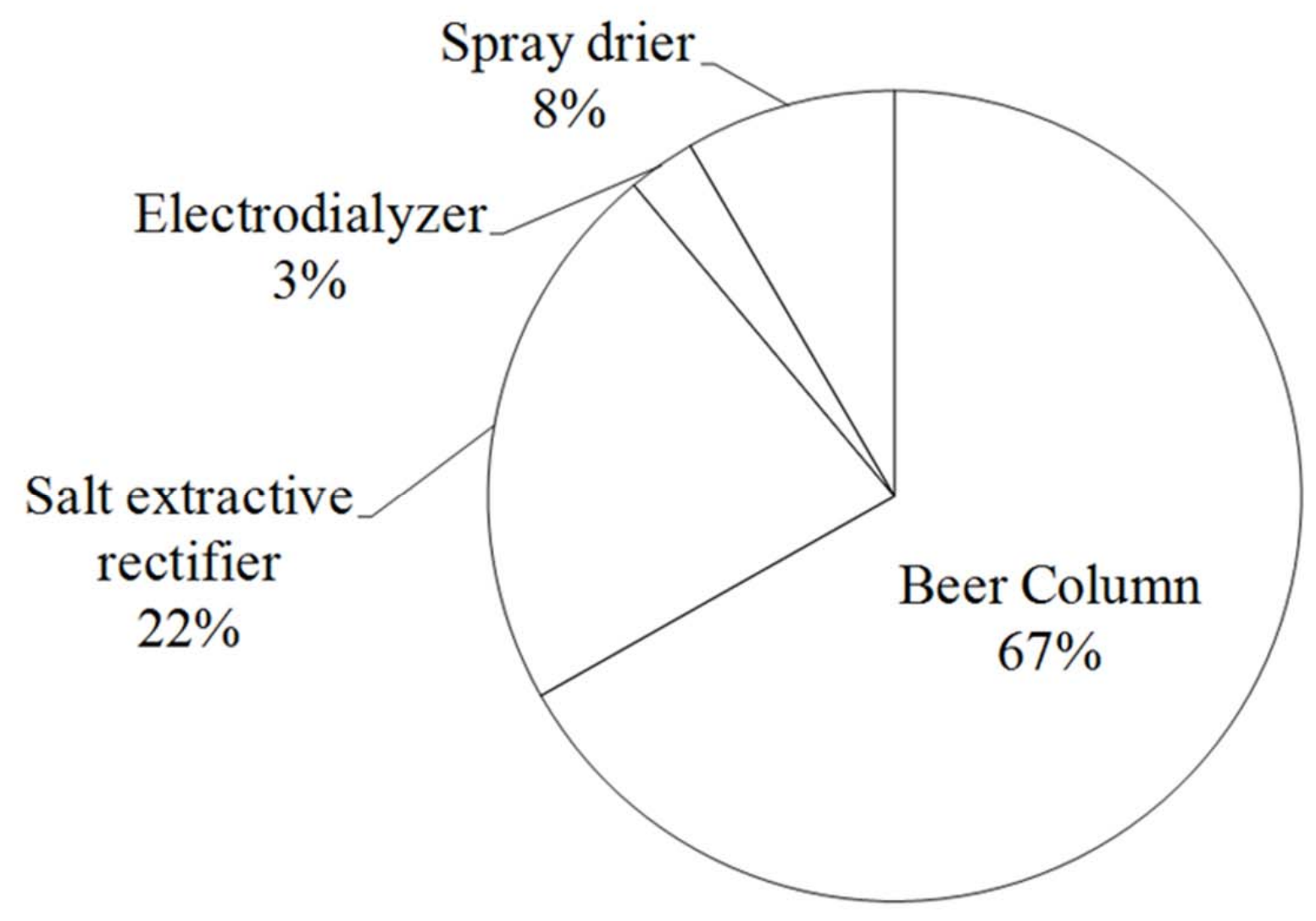

Figure 15 